\title{
Holocene erosion of the Lesser Himalaya triggered by intensified
}

\section{summer monsoon}

\author{
Peter D. Clift School of Geosciences, University of Aberdeen, Aberdeen AB24 3UE, UK \\ Liviu Giosan $]$ Jerzy Blusztajn $]$ Woods Hole Oceanographic Institution, Woods Hole, Massachusetts 02543, USA \\ $\left.\begin{array}{l}\text { lan H. Campbell } \\ \text { Charlotte Allen }\end{array}\right]$ Research School of Earth Sciences, Australian National University, Canberra, ACT 0200, Australia \\ Malcolm Pringle Department of Earth, Atmospheric and Planetary Sciences, Massachusetts Institute of Technology, \\ Cambridge, Massachusetts 02139, USA \\ $\left.\begin{array}{l}\text { Ali R. Tabrez } \\ \text { Mohammed Danish } \\ \text { M.M. Rabbani }\end{array}\right]$ National Institute for Oceanography, Clifton, Karachi 75600, Pakistan \\ Anwar Alizai Geological Survey of Pakistan, Block 2, Gulistan e Jauhar, Karachi, Pakistan \\ Andrew Carter School of Earth Sciences, University and Birkbeck College London, Gower Street, London WC1E 6BT, UK \\ Andreas Lückge Bundesanstalt für Geowissenschaften und Rohstoffe, Stilleweg 2, D-30655 Hannover, Germany
}

\begin{abstract}
Climate is one of the principal controls setting rates of continental erosion. Here we present the results of a provenance analysis of Holocene sediments from the Indus delta in order to assess climatic controls on erosion over millennial time scales. Bulk sediment Nd isotope analysis reveals a number of changes during the late Pleistocene and early Holocene (at 14-20, 11-12 and 8-9 ka) away from erosion of the Karakoram and toward more sediment flux from the Himalaya. Radiometric Ar-Ar dating of muscovite and $\mathrm{U}-\mathrm{Pb}$ dating of zircon sand grains indicate that the Lesser Himalaya eroded relatively more strongly than the Greater Himalaya as global climate warmed and the summer monsoon intensified after $14 \mathrm{ka}$. Monsoon rains appear to be the primary force controlling erosion across the western Himalaya, at least over millennial time scales. This variation is preserved with no apparent lag in sediments from the delta, but not in the deep Arabian Sea, due to sediment buffering on the continental shelf.
\end{abstract}

Keywords: erosion, Himalayas, monsoon, rivers, provenance.

\section{INTRODUCTION}

Exhumation in mountain belts is driven by the interplay of tectonically driven rock uplift and erosion controlled by glaciation and/or rainfall (Burbank et al., 2003; Hallet et al., 1996; Hodges et al., 2004). While some workers argue that climate, especially precipitation, is the primary control on erosion, and consequently on exhumation (Hodges et al., 2004; Thiede et al., 2004; Wobus et al., 2005), others favor exhumation being controlled by rock uplift driven by tectonic forces (Burbank et al., 2003). Most of these studies rely on low- or medium-temperature thermochronology measurements from the bedrock, and thus necessarily integrate erosion over relatively long periods of geological time ( $\left.>10^{6} \mathrm{yr}\right)$. Bookhagen et al. (2005) used lacustrine sediments from the Sutlej Valley to examine the processes that control erosion over millennial time scales and concluded that there was a fivefold increase in erosion of the Greater Himalaya during periods of intensified monsoon, including the early Holocene. However, this study was necessarily limited in its geographic range. In this paper we examine the erosional response of the entire northwest Himalaya to climate change since ca. $20 \mathrm{ka}$. By looking only at the past $20 \mathrm{k} . \mathrm{y}$. we eliminate changes in tectonics as the potential trigger for changes in erosion and are able to isolate the short-term erosional response of the mountains to strong climate change. Sediments of this age are relatively well dated, so that erosion can be compared with detailed monsoon reconstructions based on a number of proxies, including speleothems (Fleitmann et al., 2003; Sinha et al., 2005) and pollen assemblages (Herzschuh, 2006).
We study the erosional response of the Indus drainage basin, encompassing a number of ranges located in the western Himalaya (Fig. 1). The vast majority of the sediment eroded in this region is delivered to the delta via the Indus River and its tributaries. Consequently changes in the provenance of sediment reaching the delta can be used to understand how climate change since the last deglaciation has influenced Himalayan erosion.

\section{STRATIGRAPHY AND SAMPLING}

Samples were taken from three boreholes drilled in the delta (Fig. 1), as well as from core tops in the offshore Indus Canyon. At Keti Bundar drilling penetrated the ravinement surface that forms the base of the modern Indus delta and recovered Pleistocene sand deposited during the last glacial. Age of deposition is calculated from accelerator mass spectrometer ${ }^{14} \mathrm{C}$ dating of organic materials (see the GSA Data Repository ${ }^{1}$ ). Radiocarbon ages from below the deltaic sediments are 28.7 and $38.9 \mathrm{ka}$, suggesting reworking and mixing of older sediment prior to transgression. The Keti Bundar section shows two coarsening-upward cycles, separated by a transgressive mud deposited after ca. $8 \mathrm{ka}$. Facies analysis and sequence stratigraphy methods indicate that the delta prograded in two phases, at 8-12 ka and $8 \mathrm{ka}$ to the present (Giosan et al., 2006). Although the shoreline retreated $30 \mathrm{~km}$ northward ca. $8 \mathrm{ka}$, the delta was prograding southward during the 8-12 ka period, when rates of eustatic sea-level rise were greatest (Camoin et al., 2004). This behavior contrasts with most deltas at this time and suggests that sediment flux to the Indus delta was able to keep pace with the rising sea level, similar to the situation in the Ganges-Brahmaputra delta (Goodbred and Kuehl, 2000).

In order to assess changing patterns of erosion, the $\mathrm{Nd}$ isotope compositions of 23 bulk samples were determined, and three samples were chosen for Ar-Ar dating of muscovite grains and $\mathrm{U}-\mathrm{Pb}$ dating of zircon grains (Tables DR3 and DR4 in the GSA Data Repository.)

\section{RESULTS}

In contrast to the $\sim 1 \varepsilon_{\mathrm{Nd}}$ unit shift seen between modern and glacial sediments in the Bengal Fan (Colin et al., 1999), we use a moving average plot (Fig. $2 \mathrm{~B}$ ) to show that $\varepsilon_{\mathrm{Nd}}$ changed from $\sim 11$ to $\sim 12$ between sedi-

${ }^{1}$ GSA Data Repository item 2008018, Table DR1 $\left({ }^{14} \mathrm{C}\right.$ accelerator mass spectrometry ages for the boreholes considered in this study), Tables DR2-DR4 (bulk Nd isotope composition of sediments, Ar-Ar cooling ages of muscovite mica grains, and $\mathrm{U}-\mathrm{Pb}$ crystallization ages of zircon grains extracted from sediments), Figure DR1 (stratigraphy of the sediment cored at each of the drilling sites), and Figure DR2 (Nd isotope character of source regions in the western Himalaya), is available online at www.geosociety.org/pubs/ft2008.htm, or on request from editing@geosociety.org or Documents Secretary, GSA, P.O. Box 9140, Boulder, CO 80301, USA. 


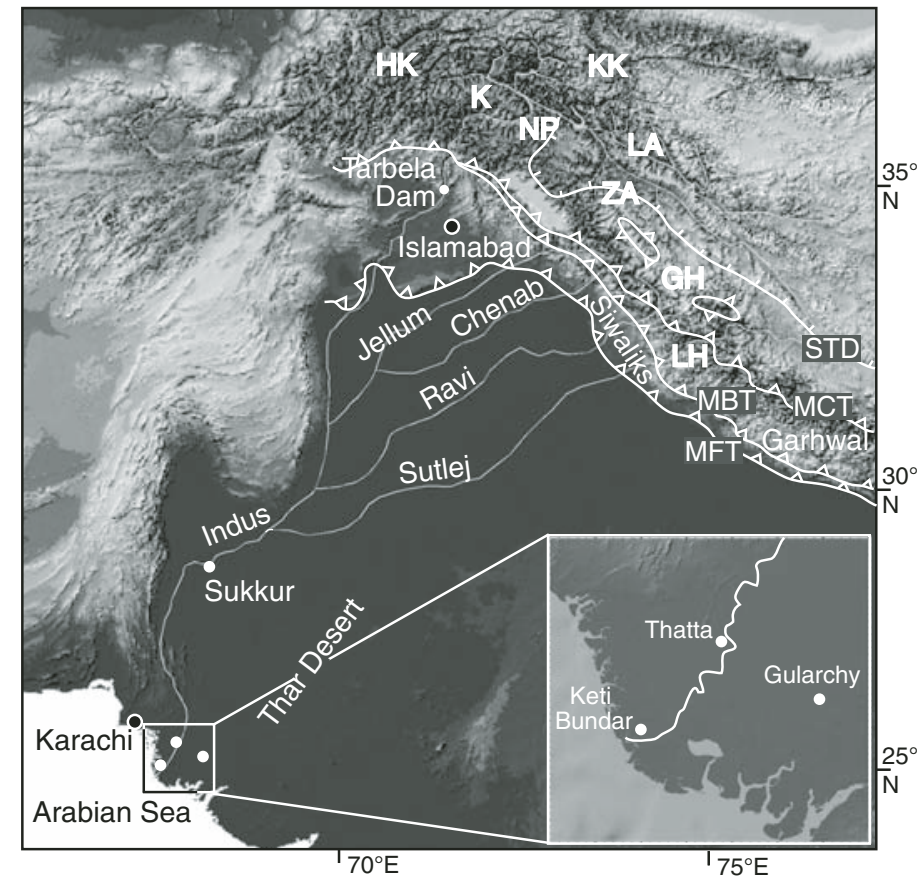

Figure 1. Shaded topographic map of Indus drainage basin, showing location boreholes in the delta, major tributaries of the modern river, and principal sediment source terrains (HK-Hindu Kush, K-Kohistan, NP-Nanga Parbat, ZA-Zanskar, LA-Ladakh, KKKarakoram, LH-Lesser Himalaya, GH-Greater Himalaya, MFTMain Frontal thrust, MBT-Main Boundary thrust, MCT-Main Central thrust: STD-South Tibet detachment).

ments of the last glacial and $14 \mathrm{ka}$, with a further decrease from $\sim 12$ to $\sim 14$ around the end of the Younger Dryas (11-12 ka), reaching $\sim 15 \mathrm{ca} .8 .7 \mathrm{ka}$. Ages assume linear sedimentation between control points, which may explain why $\varepsilon_{\mathrm{Nd}}$ falls at $12.2 \pm 0.3 \mathrm{ka}$, while the monsoon weakens at $12 \mathrm{ka}$ (Herzschuh, 2006). After a period of relatively constant $\varepsilon_{\mathrm{Nd}}(\sim 13.5)$, a further decrease to $\sim 15$ is seen since $\sim 300$ yr ago.

The Nd isotopes in clastic sediments are interpreted to reflect the average composition of the source terrains, and are controlled by the age and origin of the source rocks (Goldstein et al., 1984). In general, the older rocks of the Indian craton and Lesser Himalaya show the most negative $\varepsilon_{\mathrm{Nd}}$ values ( -26 to -23 ), while the more primitive arc rocks of the Indus suture and Transhimalaya yield positive values $(-1$ to +8$)$, with the Greater Himalaya and Karakoram having intermediate but distinct values ( -17 to -12 and -12 to -8 , respectively; Fig. DR2).

The direction of this isotopic shift after 14 ka suggests increased flux from the Lesser and/or Greater Himalaya during the early Holocene, and is almost as dramatic as the isotopic shift caused by capture of these tributaries into the Indus after $5 \mathrm{Ma}$ (Clift and Blusztajn, 2005). The postglacial change in provenance can be further constrained by considering Ar-Ar ages of detrital muscovite (Fig. 3). The Ar-Ar muscovite ages record cooling of grains in the source through the $350{ }^{\circ} \mathrm{C}$ isotherm and are thus controlled by exhumation rates (Hodges, 2003). Muscovite ages from modern and younger than $6.4 \mathrm{ka}$ sands contrast sharply with those deposited during the glacial in the appearance of many grains with cooling ages ranging from 3 to $6 \mathrm{Ma}$ and ca. $16 \mathrm{Ma}$. These younger ages are consistent with erosion from either the Lesser Himalaya or the Nanga Parbat Massif. At the same time they eliminate increased erosion of the Greater Himalaya as being the trigger for the shift to lower $\varepsilon_{\mathrm{Nd}}$ values after the last glacial because cooling ages in the western Greater Himalaya peak ca. $22 \mathrm{Ma}$. Unfortunately there are few published Ar-Ar ages from the Karakoram, but mica ages from the Transhimalaya are typically older than $45 \mathrm{Ma}$ (Dunlap and Wysoczanski, 2002), showing that these are not an important source.

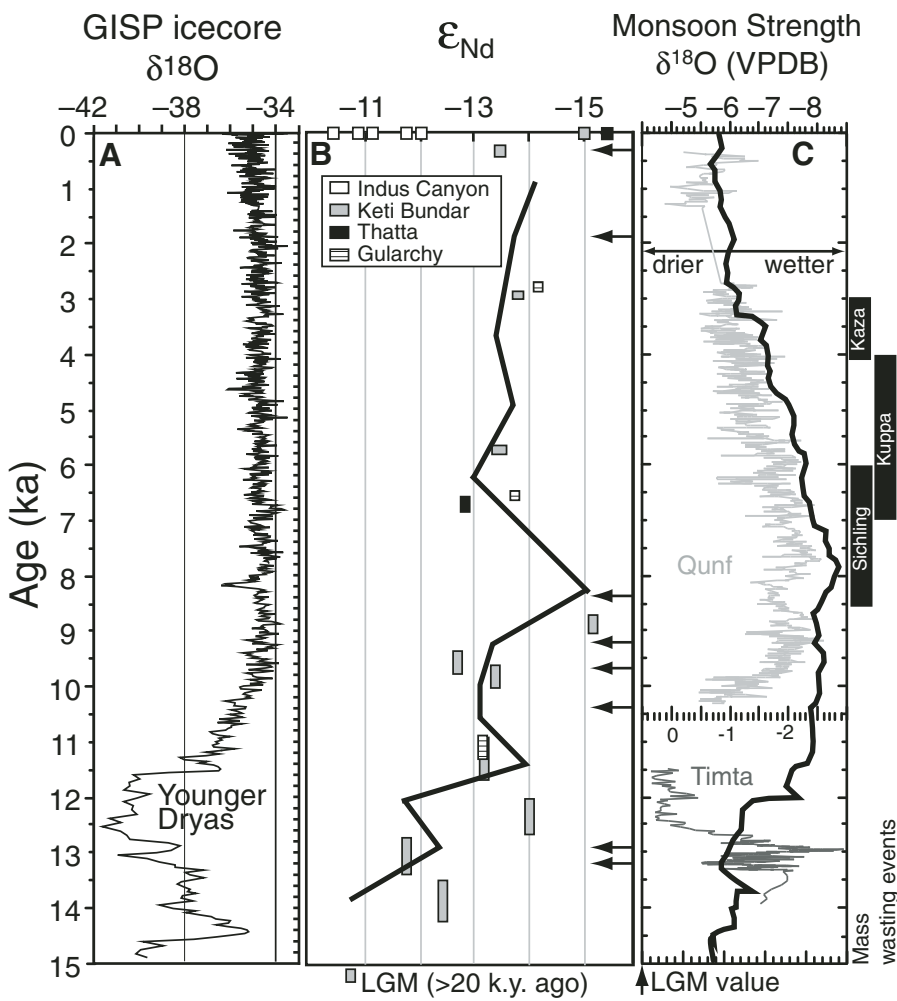

Figure 2. Nd isotopic evolution of the sediments cored from the Indus delta and Indus Canyon (B) compared with (A) the Greenland Ice Sheet Project 2 (GISP2) ice core climate record (Stuiver and Grootes, 2000), (C) the intensity of the Southwest Monsoon traced by speleothem records from Qunf and Timta Caves (Fleitmann et al., 2003; Sinha et al., 2005) in Oman and by pollen (Herzschuh, 2006) from across Asia (black line), and western Himalayan landslides (Bookhagen et al., 2005). Line in $B$ shows 3-point moving average of $\varepsilon_{\mathrm{Nd}}$ values. Depositional ages assume linear sedimentation between control points (those from Keti Bundar are shown by black arrows). See Table DR1 for age model and Table DR2 for Nd data (see footnote 1). VPDBVienna Peedee belemnite; LGM-Last Glacial Maximum.

Zircon grain ages allow the principal Holocene sediment source to be better pinpointed. The U-Pb zircon ages record the age of crustal melting $\left(\sim 950{ }^{\circ} \mathrm{C}\right)$, so that these are rarely reset by even high-grade metamorphism (Hodges, 2003). Large differences in the age and origin of source rocks across the Indus suture zone mean that zircon ages have been used as powerful sediment provenance tools in the Himalaya (Clift et al., 2004; DeCelles et al., 2000). Ruhl and Hodges (2005) argued that $>100$ grains are required to characterize a mixed sediment, so that our data can be considered statistically reliable. Figure 4 shows that only $\sim 2 \%$ of grains in modern river sands have the very young $\mathrm{U}-\mathrm{Pb}$ ages (younger than $20 \mathrm{Ma}$ ) that characterize the Nanga Parbat massif, while $\sim 19 \%$ correspond to the 50-200 Ma age range seen in Kohistan, Ladakh, or the Karakoram (Fig. 1). In contrast, the proportion of grains dated as $1.5-2.0 \mathrm{Ga}$ is much higher than seen during glacial times $(41 \%$ versus $16 \%$ ). Grains of this age range are occasionally found in the Greater Himalaya, but are abundant in the Lesser Himalaya, including those parts close to Nanga Parbat, as well as the Siwaliks (Fig. 4). Grains from the Greater Himalaya compose $42 \%$ of the load in the glacial sample and only slightly less $(\sim 38 \%)$ in the modern river. Because sedimentation rates increase greatly after $11.5 \mathrm{ka}$, even the Greater Himalaya must have eroded more rapidly during the early Holocene. This indicates that the locus of sediment eroded has shifted from north of the Indus suture (Kohistan-Karakoram) toward the southern Lesser Himalaya and to a limited extent the Greater Himalaya since $20 \mathrm{ka}$. 


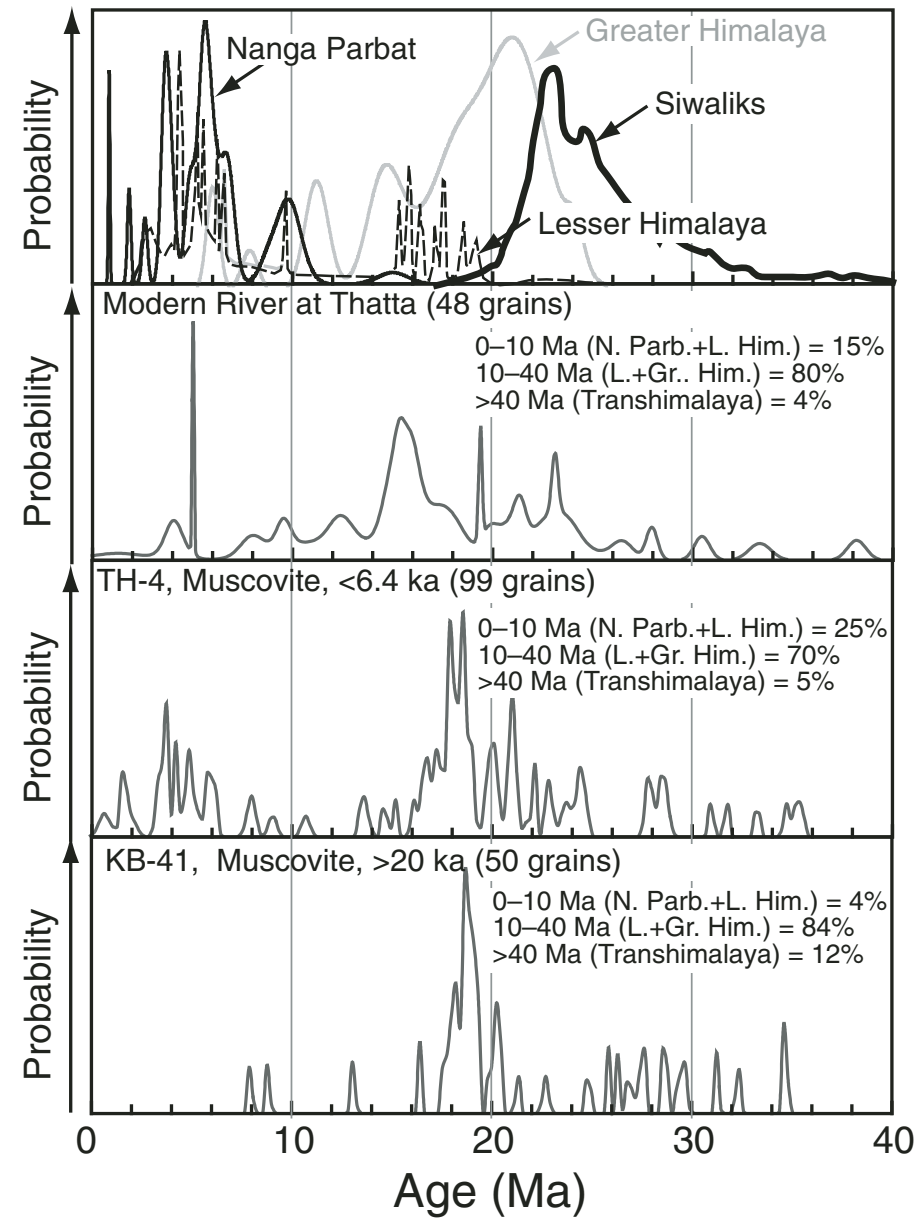

Figure 3. Probability density plots showing the range of Ar-Ar cooling ages in muscovite grains in the glacial sample, after $6.4 \mathrm{ka}$ and in the modern river (Clift et al., 2004), compared to those in possible source regions. Cooling ages for the Transhimalaya are generally older than $40 \mathrm{Ma}$. Insets show proportion of sand grains that are within age ranges distinctive of a particular provenance. See Table DR3 (see footnote 1) for data.

\section{DISCUSSION}

The Nd data provide better age resolution and more robust sampling of the average provenance compared to the single grain data, assuming there is no grain size dependence to provenance, a supposition supported by our data (Table DR2). Evolution in $\varepsilon_{\mathrm{Nd}}$ values indicates that much of the provenance evolution was completed by ca. $11 \mathrm{ka}$, at a time when the summer monsoon was strongly intensifying (Fleitmann et al., 2003; Herzschuh, 2006; Sinha et al., 2005). This pattern indicates that climate change had an immediate effect on orogenic erosion. Curiously there has been no corresponding shift in provenance since ca. $5 \mathrm{ka}$, as the monsoon weakened across Asia, although weakening appears to be less strong in southwest Asia (Fleitmann et al., 2003). Our data suggest that lag times in the transportation of the erosional signal to the delta are below the age resolution of the dating method used here, i.e., $<1000 \mathrm{yr}$. If sediment buffering in river terraces and floodplains is occurring, then this does not represent a dominant part of the river sediment load (Metivier and Gaudemer, 1999). The change in Nd since 300 yr ago is most likely caused by damming, especially at Tarbela on the main trunk river. This dam had the effect of increasing the flux of Himalayan detritus delivered by the Jellum, Chenab, Ravi, and Sutlej Rivers relative to the sediment in the trunk river (Fig. 1). In contrast, natural damming and collapse on the Sutlej at $4 \mathrm{ka}$ (Bookhagen et al., 2005) does not appear to have been volumetrically significant.

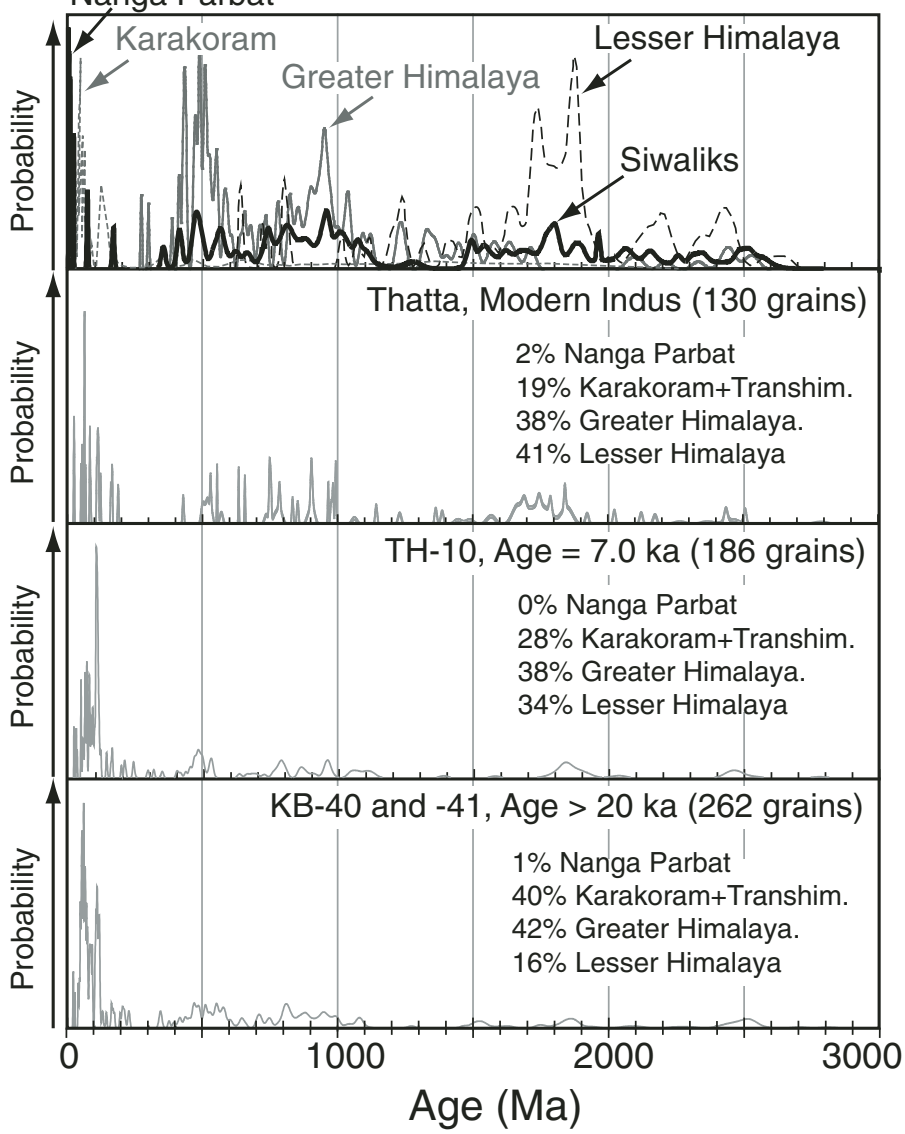

Figure 4. Probability density plots showing the range of U-Pb ages in detrital zircons compared with source terrain values. See Table DR4 (see footnote 1) for data.

The speed of the isotopic change and the temporal correlation with ice core $\delta^{18} \mathrm{O}$ and monsoon strength suggest that the distribution of the erosion intensity is linked to climate changes. Furthermore, the matching peak in $\varepsilon_{\mathrm{Nd}}$ and monsoon strength at $8.7 \mathrm{ka}$, followed by a fall in both, suggests that it is precipitation rather than temperature that is the key control. Although $\varepsilon_{\mathrm{Nd}}$ remains constant after $8 \mathrm{ka}$, when pan-Asian pollen records show decreasing monsoon strength (Herzschuh, 2006), speleothem records suggest that the Southwest Monsoon may have been more stable at that time (Fleitmann et al., 2003).

Drainage capture could also cause the provenance to change, but can be discounted here. The only abandoned channels recognized that might have previously contributed sediments to the river are on the edge of the Thar Desert (Ghose et al., 1979). These must represent flux from either the Indian craton or the Himalaya. Loss of drainage from either of these sources would have driven isotope change in the opposite direction to that reconstructed. Another possible alternative to explain the enhanced Holocene delta sedimentation would be as a response to glacial retreat after ca. $11.5 \mathrm{ka}$. However, the fact that provenance and rates of sedimentation change together at 11-14 ka eliminates the possibility that this sediment had previously been eroded and stored close to the sources or in the floodplain until monsoon intensification. Moreover, studies of Himalayan moraines indicate that the western Lesser Himalaya were unglaciated ca. $20 \mathrm{ka}$ (Owen et al., 2002).

Regional climatic data indicate a simple explanation for the link between sediment provenance and monsoon intensification during the deglacial into the early Holocene. Satellite Tropical Rainfall Mapping Mission (TRMM) mapping of annual precipitation in South Asia shows maxima over the Lesser Himalaya and at the foot of the Greater Himalaya 
(Bookhagen and Burbank, 2006). Of this precipitation, 80\% is delivered by the summer monsoon. In the Indus drainage the precipitation maximum appears to be largely focused over the Lesser Himalaya (Thiede et al., 2004), with the Greater Himalaya and especially the Karakoram located largely in the rain shadow. In years of especially strong summer monsoons, heavy rains reach north in the Greater Himalaya (Bookhagen et al., 2005), yet the Karakoram are farther north and are not affected by this process. As a result, erosion of the Lesser Himalaya, and to a lesser extent the Greater Himalaya, is closely linked to summer monsoon strength. Thus, a strong early Holocene monsoon would increase erosion in these ranges. In contrast, Karakoram erosion is more dominated by glaciation, and to the supply of water via the westerly jet (Karim and Veizer, 2002). Our data indicate that although erosion in the Greater Himalaya was enhanced during the early Holocene (Bookhagen et al., 2005), the increase was proportionately higher in the Lesser Himalaya when viewed on a regional scale.

We note that surface sediments from the deep sea Indus Canyon have $\varepsilon_{\mathrm{Nd}}$ values that are inconsistent with an origin from the Indus River since ca. $11 \mathrm{ka}$. Instead, the canyon sediments match well with delta sediment dated $13 \mathrm{ka}$ and older. This observation supports the suggestion that sealevel rise severed sediment flux to the canyon and submarine fan ca. $11 \mathrm{ka}$ (Prins and Postma, 2000), and that this route has yet to be reestablished. This observation means that there is no deep-water sediment record of changing Himalayan erosion on this millennial time scale.

\section{CONCLUSIONS}

We conclude that regional erosion rates in the western Himalaya are strongly controlled over millennial time scales both in volume and pattern by the intensity of the summer monsoon. Recent exhumation of the Lesser Himalaya is closely linked to summer monsoon intensity. The fact that the erosional pulse was rapidly communicated to the Indus delta demonstrates that sediment records in these settings provide detailed repositories of paleo-erosion records and are not significantly influenced by sediment storage in floodplains. The Indus River sediment load was not strongly buffered by this process (Metivier and Gaudemer, 1999). However, because Holocene sea-level rise stopped sediment flux to the fan after ca. $11 \mathrm{ka}$ (Prins and Postma, 2000), the deep-sea sediment record will necessarily contain a time lag between the change in erosion pattern and the time of final redeposition, presumably during the successive period of sea-level fall.

\section{ACKNOWLEDGMENTS}

This research was supported by the National Science Foundation (Ocean Sciences). We thank B. Bookhagen, G. Hilley, and J. Spotila for their reviews.

\section{REFERENCES CITED}

Bookhagen, B., and Burbank, D.W., 2006, Topography, relief, and TRMMderived rainfall variations along the Himalaya: Geophysical Research Letters, v. 33 , p. 5 .

Bookhagen, B., Thiede, R.C., and Strecker, M.R., 2005, Late Quaternary intensified monsoon phases control landscape evolution in the northwest Himalaya: Geology, v. 33, p. 149-152, doi: 10.1130/G20982.1.

Burbank, D.W., Blythe, A.E., Putkonen, J., Pratt-Sitaula, B., Gabet, E., Oskins, M., Barros, A., and Ojha, T.P., 2003, Decoupling of erosion and precipitation in the Himalayas: Nature, v. 426, p. 652-655, doi: 10.1038/nature02187.

Camoin, G.F., Montaggioni, L.F., and Braithwaite, C.J.R., 2004, Late glacial to post glacial sea levels in the western Indian Ocean: Marine Geology, v. 206, p. 119-146, doi: 10.1016/j.margeo.2004.02.003.

Clift, P.D., and Blusztajn, J.S., 2005, Reorganization of the western Himalayan river system after five million years ago: Nature, v. 438, p. 1001-1003, doi: 10.1038/nature04379.

Clift, P.D., Campbell, I.H., Pringle, M.S., Carter, A., Zhang, X., Hodges, K.V., Khan, A.A., and Allen, C.M., 2004, Thermochronology of the modern Indus River bedload; new insight into the control on the marine stratigraphic record: Tectonics, v. 23, TC5013, doi: 10.1029/2003TC001559.

Colin, C., Turpin, L., Bertaux, J., Desprairies, A., and Kissel, C., 1999, Erosional history of the Himalayan and Burman ranges during the last two glacialinterglacial cycles: Earth and Planetary Science Letters, v. 171, p. 647-660, doi: 10.1016/S0012-821X(99)00184-3.
DeCelles, P.G., Gehrels, G.E., Quade, J., LaReau, B., and Spurlin, M., 2000, Tectonic implications of U-Pb zircon ages of the Himalayan orogenic belt in Nepal: Science, v. 288, p. 497-499, doi: 10.1126/science.288.5465.497.

Dunlap, W.J., and Wysoczanski, R., 2002, Thermal evidence for Early Cretaceous metamorphism in the Shyok suture zone and age of the Khardung volcanic rocks, Ladakh, India: Journal of Asian Earth Sciences, v. 20, p. 481-490, doi: 10.1016/S1367-9120(01)00042-6.

Fleitmann, D., Burns, S.J., Mudelsee, M., Neff, U., Kramers, J., Mangini, A., and Matter, A., 2003, Holocene forcing of the Indian monsoon recorded in a stalagmite from southern Oman: Science, v. 300, p. 1737-1739, doi: 10.1126/science. 1083130.

Ghose, B., Kar, A., and Husain, Z., 1979, The lost courses of the Saraswati River in the Great Indian Desert; new evidence from Landsat imagery: Geographical Journal, v. 145, p. 446-451, doi: 10.2307/633213.

Giosan, L., Clift, P.D., Blusztajn, J., Tabrez, A., Constantinescu, S., and Filip, F., 2006, On the control of climate- and human-modulated fluvial sediment delivery on river delta development: The Indus: Eos (Transactions, American Geophysical Union), v. 87, p. 52, OS14A-04.

Goldstein, S.L., O'Nions, R.K., and Hamilton, P.J., 1984, A Sm-Nd isotopic study of atmospheric dusts and particulates from major river systems: Earth and Planetary Science Letters, v. 70, p. 221-236, doi: 10.1016/0012-821X(84)90007-4.

Goodbred, S.L., Jr., and Kuehl, S.A., 2000, Enormous Ganges-Brahmaputra sediment discharge during strengthened early Holocene monsoon: Geology, v. 28 , p. 1083-1086, doi: 10.1130/0091-7613(2000)28<1083:EGSDDS> 2.0.CO;2.

Hallet, B., Hunter, L., and Bogen, J., 1996, Rates of erosion and sediment evacuation by glaciers: A review of field data and their implications: Global and Planetary Change, v. 12, p. 213-235, doi: 10.1016/0921-8181(95)00021-6.

Herzschuh, U., 2006, Palaeo-moisture evolution in monsoonal Central Asia during the last 50,000 years: Quaternary Science Reviews, v. 25, p. 163-178, doi: 10.1016/j.quascirev.2005.02.006.

Hodges, K., 2003, Geochronology and thermochronology in orogenic systems, in Rudnick, R., ed., The crust: Amsterdam, Elsevier-Science, p. 263-292.

Hodges, K.V., Wobus, C., Ruhl, K., Schildgen, T., and Whipple, K., 2004, Quaternary deformation, river steepening, and heavy precipitation at the front of the Higher Himalayan ranges: Earth and Planetary Science Letters, v. 220, p. 379-389, doi: 10.1016/S0012-821X(04)00063-9.

Karim, A., and Veizer, J., 2002, Water balance of the Indus river basin and moisture source in the Karakoram and western Himalayas: Implications from hydrogen and oxygen isotopes river water: Journal of Geophysical Research, v. 107, p. doi: 10.1029/2000JD000253.

Metivier, F., and Gaudemer, Y., 1999, Stability of output fluxes of large rivers in South and East Asia during the last 2 million years; implications of floodplain processes: Basin Research, v. 11, p. 293-303, doi: 10.1046/ j.1365-2117.1999.00101.x.

Owen, L.A., Finkel, R.C., and Caffee, M.W., 2002, A note on the extent of glaciation throughout the Himalaya during the global last glacial maximum: Quaternary Science Reviews, v. 21, p. 147-157, doi: 10.1016/S02773791(01)00104-4.

Prins, M.A., and Postma, G., 2000, Effects of climate, sea level, and tectonics unraveled for last deglaciation turbidite records of the Arabian Sea: Geology, v. 28, p. 375-378, doi: 10.1130/0091-7613(2000)28<375:EOCSLA > 2.0.CO;2.

Ruhl, K.W., and Hodges, K.V., 2005, The use of detrital mineral cooling ages to evaluate steady state assumptions in active orogens: An example from the central Nepalese Himalaya: Tectonics, v. 24, TC4015, doi: 10.1029/2004TC001712.

Sinha, A., Cannariato, K.G., Stott, L.D., Li, H.-C., You, C.-F., Cheng, H., Edwards, R.L., and Singh, I.B., 2005, Variability of southwest Indian summer monsoon precipitation during the Bolling-Allerod: Geology, v. 33, p. 813-816, doi: 10.1130/G21498.1.

Stuiver, M., and Grootes, P.M., 2000, GISP2 oxygen isotope ratios: Quaternary Research, v. 53, p. 277-284, doi: 10.1006/qres.2000.2127.

Thiede, R.C., Bookhagen, B., Arrowsmith, J.R., Sobel, E.R., and Strecker, M.R., 2004, Climatic control on rapid exhumation along the Southern Himalayan Front: Earth and Planetary Science Letters, v. 222, p. 791-806, doi: 10.1016/j.epsl.2004.03.015.

Wobus, C., Heimsath, A., Whipple, K., and Hodges, K., 2005, Active out-ofsequence thrust faulting in the central Nepalese Himalaya: Nature, v. 434, p. 1008-1011, doi: 10.1038/nature03499.

Manuscript received 26 July 2007

Revised manuscript received 20 September 2007

Manuscript accepted 21 September 2007

Printed in USA 